\title{
An Influence of Pretreatment Conditions on Mutagen Binding of Lactobacillus paracasei subsp. tolerans JG22 against MNNG and 2-NF
}

\author{
Sung-Mee Lim* \\ Received: 5 March 2013 / Accepted: 9 May 2013 / Published Online: 30 September 2013 \\ (C) The Korean Society for Applied Biological Chemistry 2013
}

\begin{abstract}
The objectives of this study were to investigate the effect of Lactobacillus paracasei subsp. tolerans JG22 isolated from pepper leaf jangajji on the mutagenic activity of $\mathrm{N}$-methyl, $\mathrm{N}$-nitro, N-nitrosoguanidine (MNNG) and 2-nitrofluene (2-NF) and to evaluate the effect of physico-chemical pretreatment on the antimutagenic activity of the strain. The viable cells of JG22 strain displayed a significantly high $(p<0.05)$ antimutagenic activity against both mutagens tested. The antimutagenic effect of JG22 strain seems to be positively correlated with the amounts of the cells in the incubation time. This strain produced the antimutagenic activity of the maximum levels after preincubation for $30 \mathrm{~min}$. The binding of this strain against the mutagenic compounds might be mainly present in the cell wall fraction rather than the cytosol fraction. Pretreatment with proteolytic enzymes and simulated gastric and intestinal juices and at different $\mathrm{pH}$ values had no significant effect on two mutagens removal by the viable cells. However, the binding activity of the mutagen by the strain seems to be affected by heating, enzymes including $\alpha$-amylase and lysozyme, divalent ions, and sodium metaperiodate. Thus, carbohydrates consisting of the cell walls may be important elements responsible for the binding of MNNG and 2-NF by this strain. In conclusion, the binding of the mutagens to cells of JG 22 strain may play a vital role in suppressing the process of mutagenesis induced by mutagens.
\end{abstract}

Keywords ames test $\cdot$ antimutagenic activity $\cdot$ Lactobacillus paracasei subspecies tolerans $\cdot$ mutagen binding

S. -M. Lim

Department of Food Nutrition \& Science, Tongmyong University, Busan 608-735, Republic of Korea

* Corresponding author (S. -M. Lim: limsm020@tu.ac.kr)

\section{Introduction}

A mutagen is an agent of substance that causes observable phenotypic changes of DNA such as nucleotide alteration and chromosomal aberration. There are three main types of mutagens classifying by their sources: chemical (5-bromouracil, 2-aminopurine, etc.), biological (rubella and hepatitis B virus), and physical (high energy radiation and UV light) mutagens (Kodym and Afza, 2003). Among chemical mutagens, alkylating agent leads to crosslink DNA strands and chromosome breaks by two reactive alkyl groups. Deaminating agent converts amino groups to keto groups and changes hydrogen-bonding potential through oxidative deamination of amino groups in adenine, guanine, and cytosine. Intercalating agent such as acridine dyes increases rigidity and alters conformation of double helix and base analogs derivatives of the normal bases incorporated in DNA, altering base pairing properties (Singer and Kusmierek, 1982). Many mutagens arise from cigarette smoke, automotive exhaust gas, X-ray irradiation, hazardous chemicals, cooking or food processing, (un)intentional additives, and environmental contaminants (Ferguson, 2002). Presence of mutagens is not only involved in the probability of incidence for colorectal cancer but do also play a role in the pathogenesis of other chronic degenerative diseases, including atherosclerosis and heart diseases (Gaubatz, 1997).

According to previous report, the mutagenicity of direct and indirect mutagens was significantly decreased by probiotic strains including Bifidibacterium ssp., Lactobacillus bulgaricus, Enterococcus faecium, and Streptococcus thermophilus that showed the greatest protective effect against DNA damage (Burns and Rowland, 2004). Probiotics that provide numerous healthpromoting effects mainly through improving intestinal microbial balance of human and animal have been widely used in therapeutic applications (Gomes and Malcata, 1999). Several reports clearly show that lactic acid bacteria (LAB) and bifidobacteria strains isolated from dairy products are able to reduce enzymatic activities relates to mutagen formation and inhibit the activity of mutagenic chemical compounds in in vivo as 
well as in vitro systems (Hosono et al., 1986; Zhang and Ohta, 1991b; Pool-Zobel et al., 1996; Bolognani et al., 1997). Particularly, LAB and Bifidobacterium ssp. might be responsible for inactivation of mutagenic substances including $\mathrm{N}$-nitroso compounds, heterocyclic aromatic amines, polycylic aromatic hydrocarbon, mycotoxin, and fecal mutagens from various mammals. Therefore, these microorganisms can lead to reducing the levels of mutagenic compounds as well as inhibiting DNA damage (El-Nezami et al., 1998a; Faridnia et al., 2010).

Although the mechanisms of antimutagenic activity of LAB have not been clearly understood, the ability of probiotic LAB and intestinal bacteria to bind different chemical mutagens and various dietary contaminants was reported more than a decade ago (Cassand et al., 1994; El-Nezami et al., 1998a). Zhang and Ohta (1990) described the inactivation of mutagenic pyrolyzates by effectively bound to the cells of LAB. Lactobacillus rhamnosus 231 exhibits ability to bind $N$-methyl- $N$ '-nitro-N-nitrosoguanidine (MNNG) (Ambalam et al., 2011) and live bacterial cells of Lactobacillus acidophilus bound 2-nitroflurene (2-NF) permanently (Lankaputhra and Shah, 1998). Besides, the non-viable bacterial cells by heat treatment did not significantly decrease the binding of mutagenic compounds than the live cells (Lankaputhra and Shah, 1998). Binding of mutagens to the cell surface or direct inhibition of mutagenesis by the bacterial metabolites such as organic acids has been suggested to be a possible mechanism of antimutagenic activity of LAB (Hirayama and Rafter, 2000; Orrhage et al., 1994). Binding of mutagen by L. rhamnosus 231 is due to adsorption, thereby leading to removal of mutagen and is instantaneous, $\mathrm{pH}$ - and concentration-dependent. Specially, cell wall components such as polysaccharide, peptidoglycan, teicholic acid, and proteins of the strain play important role in the adsorption and detoxification of potent mutagens (Ambalam et al., 2011).

The objectives of this study were: (i) to investigate the effect of Lactobacillus paracasei subsp. tolerans JG22 isolated from pepper leaf jangajji on the mutagenic activity of MNNG and 2$\mathrm{NF}$, (ii) to study the effect of cultural condition on mutagen binding, (iii) to examine the stability of the bacteria and mutagen complexes formed, (iv) to determine a possible mechanism of the inhibition of compounds-induced mutagenesis, and (v) to evaluate the effect of physico-chemical pretreatment on the antimutagenic activity of the tested strain.

\section{Materials and methods}

Bacterial strains and growth condition. L. paracasei subsp. tolerans JG22 was obtained from pepper leaf jangajji and identified through morphology and biochemical profile and genetic analysis of 16S rRNA gene sequencing. The cultures of this strain grown aerobically in Lactobacilli MRS broth (Difco Co., Sparks, MD, USA) at $37^{\circ} \mathrm{C}$ were maintained in $20 \%(\mathrm{v} / \mathrm{v})$ glycerol at $-80^{\circ} \mathrm{C}$.

His ${ }^{-}$mutants of Salmonella typhimurium TA 98 and TA 100 used for antimutagenic test were obtained from Korean Culture Center of Microorganisms (Korea) and Molecular Toxicology Inc. (USA), respectively and freshly grown in Nutrient Broth number 2 (Oxoid, Unipath Ltd., England) containing $8 \mathrm{mg} / \mathrm{mL}$ of ampicillin at $37^{\circ} \mathrm{C}$ overnight to confirm the genotypes for histidine requirement of mutants. And then Salmonella strains were incubated for $48 \mathrm{~h}$ at $37^{\circ} \mathrm{C}$ on master plates of the minimal glucose agar medium enriched with magnesium sulfate $0.2 \mathrm{~g}$, citric acid monohydrate $2 \mathrm{~g}$, potassium phosphate dibasic $10 \mathrm{~g}$, sodium ammonium phosphate $3.5 \mathrm{~g}$, glucose $20 \mathrm{~g}$, histidine 0.05 $\mathrm{g}$, biotin $0.00074 \mathrm{~g}$, ampicillin $0.025 \mathrm{~g}$, and agar $15 \mathrm{~g}$ per liter. All strains were stored at $-80^{\circ} \mathrm{C}$.

Preparation of mutagens. MNNG, one of the most potent direct chemical mutagen was obtained from Fluka (Biochemika, Germany) and 2-NF which is potentially mutagenic and carcinogenic compound was purchased from Sigma-Aldrich (USA). Stock solutions of two mutagens were dissolved in dimethyl sulfoxide (DMSO, Sigma-Aldrich) at a concentration of $1 \mathrm{~g} / \mathrm{mL}$ and stored at $-20^{\circ} \mathrm{C}$. Working solutions of MNNG and 2-NF were obtained with $0.05 \mathrm{M}$ citrate buffer ( $\mathrm{pH}$ 6.2) and $0.05 \mathrm{M}$ sodium phosphate buffer ( $\mathrm{pH}$ 7.4) just before use, respectively. MNNG and 2-NF which cause base pair substitutions were used without S9-mix.

Cell preparation and determination of mutagen concentration. JG22 strain to obtain the stationary phase cells was inoculated into MRS broth and incubated for $24 \mathrm{~h}$ at $37^{\circ} \mathrm{C}$. The cultures were harvested by centrifuging $\left(7,000 \times \mathrm{g}, 15 \mathrm{~min}, 4^{\circ} \mathrm{C}\right)$ and separated into cell pellets and cell-free supernatants. The pellets were washed twice with phosphate buffer saline (PBS, pH 7.0) and resuspened in same buffer to yield $1.0 \times 10^{10} \mathrm{CFU} / \mathrm{mL}$ (optical density at $600 \mathrm{~nm}$ was 1.5 ). The cell-free supernatants collected after centrifugation were filtered through $0.45 \mu \mathrm{m}$ Millipore membrane filter (USA) for the antimutagenicity evaluation.

In order to select a suitable range of concentration of the mutagens, MNNG and 2-NF were used at concentration of 0.1 , $0.5,1.0$, and $2.0 \mu \mathrm{g} /$ plate and the concentrations in the linear parts of dose-responses curves were determined according to the method of Maron and Ames (Maron and Ames, 1983). The linear slope of the dose-response curve represents the mutagenic activity, i.e. the number of induced histidine revertants per $\mu \mathrm{g}$ of the mutagens. Based on biologic responses from preliminary experiments, the final concentrations of $1 \mu \mathrm{g} /$ plate for MNNG and $1 \mu \mathrm{g} /$ plate for 2-NF were chosen, which caused a significant frequency of his + revertants with no observable toxicity on the cell survival.

Ames test. The antimutagenicity of $L$. paracasei subsp. tolerans JG22 was determined by measuring the extent of decrease in mutation of S. typhimurium TA98 and TA100 strain induced by MNNG and 2-NF according to the preincubation Ames test (Maron and Ames, 1983). In brief, the following components were added to the sterile glass tubes: cell suspension or cell-free supernatant of JG22 strain $(0.1 \mathrm{~mL})$, overnight culture of $S$. typhimurium strains TA98 or TA100 $(0.1 \mathrm{~mL})$, each mutagen solution $(0.1 \mathrm{~mL})$, and PBS $(0.7 \mathrm{~mL})$. After preincubation for $30 \mathrm{~min}$ at $37^{\circ} \mathrm{C}$ with agitation $(100 \mathrm{rpm})$ in the dark, the mixture 
solutions were combined with $2 \mathrm{~mL}$ of molten top agar $(0.5 \%, \mathrm{w} /$ v) containing $0.05 \mathrm{mM}$ L-histidine/biotine and $0.09 \mathrm{M} \mathrm{NaCl}$, mixed by gently vortexing, and poured onto a minimal glucose agar $(1.5 \%, \mathrm{w} / \mathrm{v})$ plate. When counting the cell numbers of histidine revertants after incubation for $48 \mathrm{~h}$ at $37^{\circ} \mathrm{C}$, the number of is $^{+}$revertant colonies on the plates was counted in each plate taking into account possible toxic effects and compared with the control. Positive control was consisted of S. typhimurium cells, mutagen, and buffer solution without the cell cultures of JG22 strain, while negative control was prepared with equivalent amount of the buffer instead of the mutagen and the tested cell cultures, which is required to establish the number of colonies that arise spontaneously for $S$. typhimurium TA98 and TA100. The experiments were performed in triplicate. The antimutagenic effect was expressed as a percentage of the inhibition of reverse mutations as follows: Inhibition $(\%)=[(a-b) /(a-c)] \times 100$. Where a is the number of histidine revertants induced by the mutagen in the absence of the JG22 strain, b is the number of histidine revertants induced by the mutagen in the presence of the JG22 strain, and $\mathrm{c}$ is the number of spontaneous revertants in the absence of the mutagen.

Effects of cultural age on antimutagenic activity. The cultures of JG22 strain incubated in MRS broth for $48 \mathrm{~h}$ at $37^{\circ} \mathrm{C}$ were collected at specified incubation time, centrifuged $(7,000 \times \mathrm{g}, 10$ min, $4^{\circ} \mathrm{C}$ ), washed with PBS ( $\mathrm{pH} 7.0$ ), and resuspended in same buffer. The samples obtained at the specific time were serially diluted in sterile PBS and plated on MRS agar by pour plate method to calculate the viable cell counts. Simultaneously, the coincubation of the cultures of JG22 strain with MNNG $(1 \mu \mathrm{g} /$ plate $)$ or 2-NF (1 $\mu \mathrm{g} /$ plate) and Salmonella cells was carried out for 30 min at $37^{\circ} \mathrm{C}$ under shaking $(100 \mathrm{rpm})$. And then, the antimutagenicity of cell cultures of JG22 strain was determined by Ames test as mentioned above.

Effects of preincubation time on antimutagenic activity. The cell suspensions $\left(1.0 \times 10^{10} \mathrm{CFU} / \mathrm{mL}\right)$ of JG22 strain in PBS, the overnight culture of $S$. typhimurium strains TA98 or TA100 grown in nutrient broth, and each mutagen $(1 \mu \mathrm{g} /$ plate for MNNG or $1 \mu \mathrm{g} /$ plate for 2-NF) were mixed and preincubated at $37^{\circ} \mathrm{C}$ with gentle shaking for $15,30,45$, or $60 \mathrm{~min}$. After co-incubation, this reaction mixture was used to determine the antimutagenic activity of the tested strain by Ames test.

Stability of mutagen binding. The cells obtained from stationary phase were collected by centrifugation $\left(7,000 \times \mathrm{g}, 10 \mathrm{~min}, 4^{\circ} \mathrm{C}\right)$ and washed twice with PBS ( $\mathrm{pH} 7.0$ ), and then the bacterial pellets were resuspended in the same buffer and co-incubated with each mutagen for $30 \mathrm{~min}$ at $37^{\circ} \mathrm{C}$. Then, the supernatants harvested by centrifugation were collected to measure the mutagen released from the bacteria. Meanwhile, in order to assess the stability of the bacteria-mutagen complex, the bacterial pellets that had been exposed to mutagen were subjected to three subsequent additional washes with Milli-Q water and incubated for $10 \mathrm{~min}$ at room temperature. Each suspension was centrifuged and the released mutagen from the cell-free fraction and the mutagen remaining in the pellets were quantified by high performance liquid chromato- graphy (HPLC, Shimadzu, Japan) analysis by the method of Srinivasan et al. (2007) with minor modification. The mutagen was separated on a Zorbax XDB-C18 column $(250 \times 4.6 \mathrm{~mm}$, France), with a mobile phase of solvent $\mathrm{A}$ (water with $0.1 \%$ trifluoroacetic acid) and solvent B (acetonitrile with $0.1 \%$ trifluoroacetic acid). For gradient elution, solvent B was increased from 1 to $15 \%$ within $30 \mathrm{~min}$ and then drastically increased to $90 \%$ within $10 \mathrm{~min}$. The flow rate was maintained at $1 \mathrm{~mL} \mathrm{~min}^{-1}$ and the UV detection was set at $230 \mathrm{~nm}$. The percentage of the mutagen bound to the bacteria was calculated using the equation: [1-(mutagen peak area of sample/mutagen peak area of control)] $\times$ 100. All assays were performed in triplicate.

Extraction of cell wall fractions, peptidoglycans, and exopolysaccharides. Cell wall fractions were prepared according to the method of Gopal and Reilly (1995). Cell suspensions in PBS ( $\mathrm{pH} 7.0$ ) containing $1.0 \times 10^{10}$ cells were pelleted by centrifugation $\left(7,000 \times \mathrm{g}, 10 \mathrm{~min}, 4^{\circ} \mathrm{C}\right)$ and then the precipitated cells were resuspended homogeneously in cold distilled water. A sample of the cell suspension was disintegrated by ultrasonication using a sonicator (Qsonical, USA). Sonication was carried out by $10 \mathrm{~s}$ cycles, each followed by a $20 \mathrm{~s}$ cooling interval. Unbroken cells and debris were removed by centrifugation at $1,000 \times \mathrm{g}$ for $10 \mathrm{~min}$ at $4^{\circ} \mathrm{C}$. Then crude cell walls were sedimented by centrifugation $\left(15,000 \times \mathrm{g}, 25 \mathrm{~min}, 4^{\circ} \mathrm{C}\right)$, resuspended in PBS (pH 7.0), and used as the crude cell wall fraction. A streak of the fraction on the MRS agar plate did not show the growth after incubation aerobically at $37^{\circ} \mathrm{C}$, indicating complete disruption of the cells by sonication. The cell walls were further washed two times in $15 \mathrm{mM} \mathrm{NaCl}$, followed by washing in $50 \mathrm{mM}$ Tris-hydroxymethyl-aminomethane hydrochloride, and diluted to twice the volume with $10 \mathrm{mM}$ PBS (pH 7.0). The mixtures were added to a final concentration of 50 $\mu \mathrm{g} / \mathrm{mL}$ RNase and DNase, incubated for $90 \mathrm{~min}$ at $37^{\circ} \mathrm{C}$, and centrifuged $\left(15,000 \times \mathrm{g}, 25 \mathrm{~min}, 4^{\circ} \mathrm{C}\right)$. The cell walls washed with PBS were treated with $20 \mathrm{~g} / \mathrm{L}$ of sodium dodecylsulfate (SDS) and heated for $2 \mathrm{~h}$ at $70^{\circ} \mathrm{C}$ to remove the cell membrane. The cell walls were washed with PBS to remove SDS, centrifuged to collect the residue, lyophilized to yield the dry cell fraction, and used as the purified cell wall preparation.

Meanwhile, cell wall polysaccharides and peptidoglycans were prepared according to the method described by Sreekumar and Hosono (1998d). The isolated cell walls were treated with $5 \%(\mathrm{w} / \mathrm{v})$ trichloroacetic acid (TCA) for $15 \mathrm{~min}$ at $90^{\circ} \mathrm{C}$ and the mixtures after cooling were centrifuged at $11,000 \times \mathrm{g}$ for $15 \mathrm{~min}$ to obtain the peptidoglycans (TCA insoluble fraction). The precipitate was washed first with 5\% TCA, lyophilized, and used as peptidoglycan preparation. Meanwhile, polysaccharides were collected from the supernatant (TCA soluble fraction) of the cell wall fractions by addition of two volumes of cold $95 \%(\mathrm{v} / \mathrm{v})$ ethanol followed by an overnight incubation at $4^{\circ} \mathrm{C}$. The precipitate containing the polysaccharides was collected by centrifugation at $2,000 \times \mathrm{g}$ for $15 \mathrm{~min}$ at $4^{\circ} \mathrm{C}$, washed with ethanol and ether, and then lyophilized. The prepared cell wall fractions, peptidoglycans, or polysaccharides were suspended in PBS (pH 7.0) and coincubated with each mutagen, and then the mutagen binding of the 
cell wall and components of the tested strain was determined by HPLC as mentioned above.

Influence of different treatments on antimutagenic effect. To study the influence of various factors on the survival and mutagen binding of $L$. paracasei subsp. tolerans JG22, the cell suspensions were pretreated with $\mathrm{pH}$, heating, enzymes, metal ions, simulated intestinal juices, and sodium metaperiodate. Firstly, to observe the effect of varying $\mathrm{pH}$ on mutagen binding of the tested strain, the cell pellets containing $1.0 \times 10^{10} \mathrm{CFU} / \mathrm{mL}$ were suspended in 100 $\mathrm{mM}$ of glycine-HCl buffer ( $\mathrm{pH} 2.0$ and 3.0), acetate buffer $(\mathrm{pH}$ 4.0 and 5.0), PBS (pH 6.0 and 7.0), and tris buffer (pH 8.0 and 9.0), respectively and incubated for $2 \mathrm{~h}$ at $37^{\circ} \mathrm{C}$. In addition, the cell suspensions in PBS ( $\mathrm{pH} 7.0$ ) were heat treated in test tube for $60 \mathrm{~min}$ at $80^{\circ} \mathrm{C}$, for $30 \mathrm{~min}$ at $100^{\circ} \mathrm{C}$, or for $15 \mathrm{~min}$ at $121^{\circ} \mathrm{C}$. After heat treatment, the cells were cooled immediately in ice water, and vortexed for $5 \mathrm{~min}$ to break any coagulum formed during heating. For enzyme pretreatment, $1 \mathrm{mg} / \mathrm{mL}$ solution of $\alpha$-amylase $(50 \mathrm{mM}$ sodium acetate, $\mathrm{pH} 6.0)$, lysozyme $(50 \mathrm{mM}$, sodium phosphate, $\mathrm{pH} 8.8)$, protease $(50 \mathrm{mM}$ tris- $\mathrm{HCl}, \mathrm{pH} 7.5)$, pepsin $(10 \mathrm{mM}$ citrate, $\mathrm{pH} 2.0)$, trypsin and chemotrypsin $(50 \mathrm{mM}$ tris- $\mathrm{HCl}, \mathrm{pH}$ 8.0 ), and lipase (50 mM tris- $\mathrm{HCl}, \mathrm{pH} 7.5)$ was prepared in optimal buffer. The solutions of enzyme were added to the bacterial pellet suspension and incubated for $2 \mathrm{~h}$ at $37^{\circ} \mathrm{C}$. The reaction was terminated by boiling the mixture for $5 \mathrm{~min}$. In addition to, the cells of JG22 strain treated with a metal salts were prepared as follows. Fresh harvested bacteria $\left(1 \times 10^{10} \mathrm{CFU} / \mathrm{mL}\right)$ were resuspended in PBS (pH 7.0) and exposed to $50 \mathrm{mM}$ of each metal ion such as $\mathrm{NaCl}, \mathrm{CaCl}_{2}$, and $\mathrm{MgCl}_{2}$ for $3 \mathrm{~h}$ at $37^{\circ} \mathrm{C}$ with shaking. To evaluate the effect of intestinal juices on antimutagenic activity, the pellets of the tested strain were incubated in simulated gastric juice $[\mathrm{NaCl}$ $125 \mathrm{mM}, \mathrm{KCl} 7 \mathrm{mM}, \mathrm{NaHCO}_{3} 45 \mathrm{mM}$, and pepsin (SigmaAldrich) $1 \mathrm{mg} / \mathrm{ml}, \mathrm{pH} \mathrm{2.0]}$ for $2 \mathrm{~h}$ at $37^{\circ} \mathrm{C}$ and artificial intestinal fluid [pancreatine (Sigma-Aldrich) $1 \mathrm{mg} / \mathrm{mL}$ and bovine bile (Sigma-Aldrich) $0.05 \%, \mathrm{pH} 8.0 \mathrm{]}$ for $3 \mathrm{~h}$ at $37^{\circ} \mathrm{C}$, respectively. Meanwhile, the solution $(10 \mathrm{mg} / \mathrm{mL})$ of sodium metaperiodate (Sigma-Aldrich) was prepared in $0.01 \mathrm{M}$ acetate buffer ( $\mathrm{pH} 4.5$ ). Sodium metaperiodate treatment against the cell suspension was carried out for $24 \mathrm{~h}$ at $4^{\circ} \mathrm{C}$ and then ethylene glycol was added to destroy the excess metaperiodate present in the reaction mixture at the end of the reaction. After each treatment, the cell pellets harvested by centrifugation $\left(7,000 \times \mathrm{g}, 10 \mathrm{~min}, 4^{\circ} \mathrm{C}\right)$ were washed twice with PBS (pH 7.0) and incubated with each mutagen. The mutagen binding from cell preparation were then determined as before. Besides, the cell survival was estimated as the ratio of the remaining cell counts to the initial cell counts using pour plate method.

Statistical analysis. All experiments on antimutagenic activity evaluated using Ames test were repeated three times using duplicate plates. The results are expressed as the mean number of his $^{+}$revertants per plate \pm standard deviation (SD). Each experiment on mutagen binding and cell viability was conducted in triplicate and compared with the control. Statistical analysis of the antimutagenic activity, mutagen binding, and cell viability of the tested strain was carried out using paired t-test of SPSS package (version 12.0, SPSS, Chicago, USA) was used to identify significant differences $(p<0.05)$.

\section{Results and Discussion}

Previously, it was observed in our laboratory that L. paracasei subsp. tolerans JG22 can be regarded as a putative probiotic, since this strain showed high survival in the artificial gut environment and the adherence capability to Caco- 2 cells. In addition, the viable JG22 strain significantly exhibited the antimutagenicity by binding of the mutagen to the cell surface when co-incubation with MNNG and 2-NF (unpublished data). In this study, we provided the additional information regarding the possible mechanism of the inhibition of mutagenesis induced by MNNG or 2-NF and the influence of cultural condition, preincubation time, and physico-chemical pretreatments on the mutagen binding of JG22 strain.

Antimutagenic effect of $L$. paracasei subsp. tolerans JG22 cells against MNNG and 2-NF. The antimutagenic activities of the cell pellets and the cell-free supernatants of $L$. paracasei subsp. tolerans JG22 against MNNG and 2-NF are shown in Table 1. MNNG is an alkylating agent which relates to the chemicals causing a non-replicating DNA and 2-NF is an intercalating agent which induces directly frameshift mutations in DNA (Paul et al., 1994). JG22 strain was found to exhibit a significantly high $(p<0.05)$ antimutagenic activity against both mutagens tested. The viable cells of the strain had higher inhibitory effects on the

Table 1 Antimutagenic activity of L. paracasi subsp. tolerans JG22 strain against MNNG and 2-NF in S. typhimurium TA98 and TA100

\begin{tabular}{|c|c|c|c|c|c|c|c|c|c|c|}
\hline & \multicolumn{4}{|c|}{ MNNG (1 $\mu \mathrm{g} /$ plate $)$} & \multirow{3}{*}{$\begin{array}{l}\text { Viability } \\
(\%)\end{array}$} & \multicolumn{5}{|c|}{ 2-NF (1 $\mu \mathrm{g} /$ plate $)$} \\
\hline & \multicolumn{2}{|c|}{$\begin{array}{l}\text { Number of revertants } \\
\quad(\text { plate } \pm \text { SD) }\end{array}$} & \multicolumn{2}{|c|}{ Inhibition (\%) } & & \multicolumn{2}{|c|}{$\begin{array}{l}\text { Number of revertants } \\
\quad(\text { plate } \pm \text { SD) }\end{array}$} & \multicolumn{2}{|c|}{ Inhibition (\%) } & \multirow[t]{2}{*}{$\begin{array}{l}\text { Viability } \\
(\%)\end{array}$} \\
\hline & TA98 & TA100 & TA98 & TA100 & & TA98 & TA100 & TA98 & TA100 & \\
\hline Positive control & $130 \pm 22$ & $1281 \pm 52$ & & & \multirow{4}{*}{$99.81 \pm 0.52$} & $308 \pm 28$ & $528 \pm 39$ & & & \multirow{4}{*}{$99.93 \pm 0.35$} \\
\hline Spontaneous & $27 \pm 5$ & $180 \pm 29$ & & & & $29 \pm 4$ & $166 \pm 28$ & & & \\
\hline Cell pellets & $98 \pm 11 *$ & $842 \pm 33^{*}$ & $30.47 \pm 4.58$ & $39.88 \pm 0.88$ & & $165 \pm 21^{*}$ & $286 \pm 30 *$ & $51.37 \pm 1.90$ & $66.84 \pm 0.46$ & \\
\hline Cell-free supernatants & $132 \pm 23$ & $1189 \pm 41^{*}$ & $\mathrm{ND}^{\mathrm{b})}$ & $8.34 \pm 0.83$ & & $297 \pm 25$ & $489 \pm 25$ & $3.87 \pm 0.75$ & $10.70 \pm 3.55$ & \\
\hline
\end{tabular}

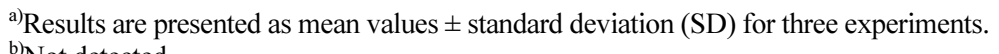

b) Not detected.

* Significantly differ $(p<0.05)$ from the control group by paired t-test. 
mutagenicity of 2-NF than MNNG in Ames test. The viable cells of $L$. paracasei subsp. tolerans JG22 showed $66.8 \%$ inhibitory effect on the number of revertants in S. typhimurium TA100 induced by $2-\mathrm{NF}$, but the cell-free supernatant of the strain only showed $10.7 \%$ antimutagenicity. Besides, the cell-free supernatant of JG22 strain did not exhibit any antimutagenic activity against MNNG in S. typhimurium TA98. The wide range of inhibition of JG22 strain toward MNNG and 2-NF can be attributed to the difference in the mode of action or activation pathway of different mutagens like the results reported by Nadathur et al. (1994). The present finding is in accordance with results of Lo et al. (2004), who reported that the cells of Bifidobacterium lactis Bb-12 and Bifidobacterium longum CCRC 14634 showed higher antimutagenic activity than their supernatants. However, Mobarez et al. (2007) unlike our result displayed the characteristic antimutagenic activities by the cell-free supernatants as well as the viable cells preincubated with mutagenic factor. Park and Rhee (2001) reported that culture supernatant rather than dry cells and cell-free extract possessed the highest activity and the antimutagenic ratio of the supernatant was $98.4 \%$ against MNNG on strain TA100 and 57.3\% against NQO on strain TA98. Meanwhile, Lankaputhra and Shah (1998) reported a strong antimutagenicity of the metabolites such as butyrate and acetate produced by probiotic Lactobacillus and Bifidobacterium strains against several mutagens and promutagens.

According to the previously proposed studies, it has been well established that various strains originating from dairy products fermented by probiotic starters displayed the antimutagenic activity against a number of direct and indirect acting mutagens (Sreekumar and Hosono, 1998c; Mobarez et al., 2007). The antimutagenic activity of the cell pellets of $L$. paracasei subsp. tolerans JG22 against MNNG was higher than that of $L$. acidophilus 2401, Bifidobacterium bifidum 1900, Bifidobacterium breve 1930, and Bifidobacterium pseudolongum 20099. Moreover, the strain against 2-NF exhibited the higher antimutagenic activity than L. acidophilus 2415 and Bifidobacterium thermophilum 20210 (Lankaputhra and Shah, 1998).

The major mechanisms of the antimutagenesis by probiotic bacteria were broadly described by DeFlora et al. (1992). Namely, the antimutagenic property has been associated with inducer of metabolic enzyme such as glutathione transferase, which tends to inhibit target mutagens. Antimutagenic agents which have antioxidant or free radical scavenging activity can readily scavenge most free radicals. In addition, antimutagens can prevent the metabolic activation or bioactivation to an electrophilic from the active species that can react with the DNA and are able to scavenge harmful compounds through binding or adsorption of mutagens to the cell surface of specific bacteria including probiotic organisms. These results indicated that the antimutagenic activity of JG22 strain may be due to the interactions of the viable cells or the cells' constituents with the mutagen.

Meanwhile, S. typhimurium TA100 strain performed better as a mutagenicity indicator than $S$. typhimurium TA98 strain against two mutagens used in this study. The viable cells of JG22 strain

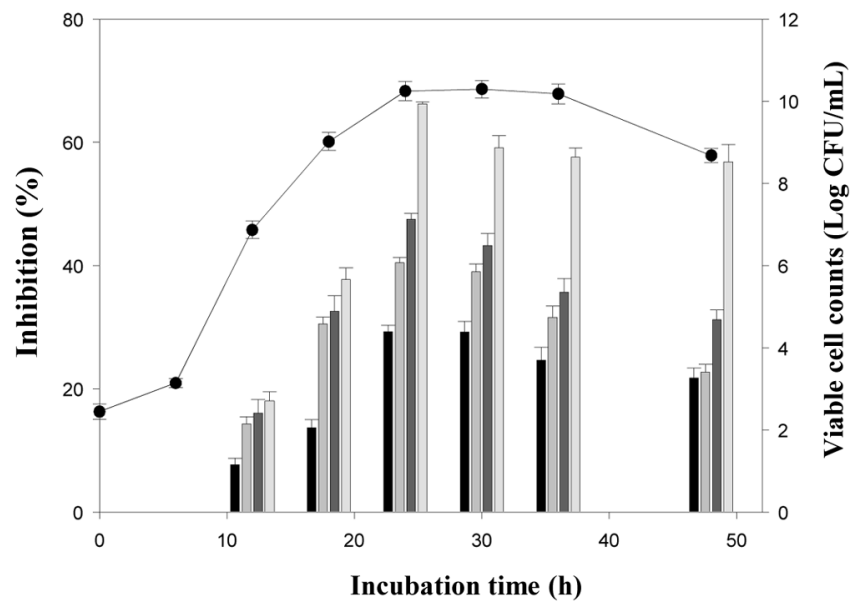

Fig. 1 Viable cell counts and antimutagenic activity of $L$. paracasei subsp. tolerans JG22 in the course of culture growth. Bars represent means of triplicate assays and error bars represent SD. (O), viable cell counts; ( $\square$ ), the antimutagenic activity on MNNG-induced mutations in S. typhimurium TA98; ( $\square$ ), the antimutagenic activity on MNNGinduced mutations in S. typhimurium TA100; ( $\square$ ), the antimutagenic activity on 2-NF-induced mutations in $S$. typhimurium TA98; ( $\square$ ), the antimutagenic activity on 2-NF-induced mutations in S. typhimurium TA100.

reduced the level of MNNG-induced mutations by $29 \%$ in TA98 and by $40 \%$ in TA100 and inhibited the mutagenic effects of 2-NF on TA98 and TA100 by 48 and $67 \%$, respectively. These results emphasized that since the viable cells of JG22 strain strongly suppressed the mutagenicity of MNNG and 2-NF, the strain should be able to maintain their viability in the intestine to provide efficient inhibition of the mutagens. Probiotic microorganisms could possibly play a vital role in lowering the risk of cancer development by suppressing the activity of mutagens in the intestine (Lo et al., 2002; Mobarez et al., 2007). Anti-mutagens, which act to lower the mutation rate either by inactivating mutagens or by interfering in the process of mutagenesis can prevent human cancer and genetic disease (Kim et al., 2000), because they can destroy mutagens in body cells and block mutagens that change of DNA sequence and damage of genetic material in chromosomal structures (Ruan et al., 1989).

Effects of cultural age and preincubation time on antimutagenic activity. Fig. 1 shows the relationship between the growth phases of the cells and the antimutagenic activity. The viable cell counts and antimutagenicity were gradually increased as the incubation time elapsed until log phase. The antimutagenicity was detectable in the cell cultures for the first time after $12 \mathrm{~h}$, the middle log growth phase. The greatest extent of the antimutagenicity against two mutagens was found in the cells grown to the stationary phase $(24 \mathrm{~h})$. Between 24 and $36 \mathrm{~h}$ the cell density was maintained to the high level, but the antimutagenicity was steadily decreased for this time. Therefore, the antimutagenic effect of JG22 strain against MNNG and 2-NF seems to be positively correlated with the amounts of the cells in the incubation time.

The binding of mutagen by L. rhamnosus Lr 231 was dependent 


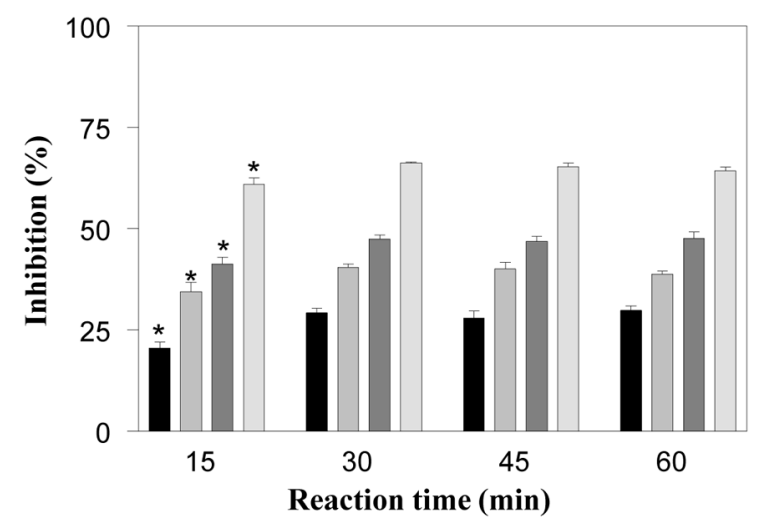

Fig. 2 Effects of incubation time on the mutagen binding of $L$. paracasei subsp. tolerans JG22 strain. Bars represent means of triplicate assays and error bars represent SD. *Significantly differ $(p<0.05)$ from the control group by paired t-test. ( $\boldsymbol{\square})$, the antimutagenic activity on MNNGinduced mutations in S. typhimurium TA98; $(\square)$, the antimutagenic activity on MNNG-induced mutations in S. typhimurium TA100; ( $\square$ ), the antimutagenic activity on 2-NF-induced mutations in S. typhimurium TA98; ( $\square$ ), the antimutagenic activity on 2-NF-induced mutations in $S$. typhimurium TA100.

on culture age and the optimum binding of acridine orange (AO), MNNG, and 2-amino-3,8-dimethylimidazo[4,5-f]-quinoxaline (MeIQx) was observed to occur with $24 \mathrm{~h}$ old culture (Ambalam et al., 2011). Vorobjeva et al. (2001) noticed that the highest antimutagenic activity against 4-NQO was found in the culture liquid of Propionibacterium shermanii cells grown for $24 \mathrm{~h}$, which was higher than the antimutgenicity of the cells after $72 \mathrm{~h}$ incubation. Park et al. (1998) confirmed that the cell wall of LAB isolated from kimchi exhibited the antimutagenic activity against MeIQx and 3-amino-1-metyl-5H-pyrido [4,3-b] indole (Trp-P-2) depending on the cell concentration, whereas the antimutagenic activity of cytosol of those strain was very low. El-Nezami et al. (1998b) reported that L. rhamnosus strain GG and L. rhamnosus strain LC can significantly remove aflatoxin $B_{1}$ and the removal of aflatoxin $B_{1}$ by these two strains was both incubation temperature and bacterial concentration dependent.

Fig. 2 shows the effect of different preincubation time on the recovered colony numbers of the $S$. typhimurium strain TA98 and TA100. The antimutagenic activity of $L$. paracasei subsp. tolerans JG22 against MNNG and 2-NF was examined by preincubation of the viable cells with the mutagen for $15,30,45$, and $60 \mathrm{~min}$ at $37^{\circ} \mathrm{C}$. In S. typhimurium TA98 and TA100, the preincubation time for $30 \mathrm{~min}$ of the cells with MNNG or 2-NF was also found to result in a significant increase $(p<0.05)$ in the antimutagenicity of the strain compared to the level observed in preincubation for 15 min. L. paracasei subsp. tolerans JG22 strain produced the antimutagenic activity of the maximum levels in $S$. typhimurium TA100 after preincubation for $30 \mathrm{~min}$. Whereas, no significant increase in the antimutagenicity was noted with the further extension of preincubation from 45 to $60 \mathrm{~min}$.

These observations clearly demonstrated that a desmutagenic effect by a direct interaction and rapid process of the cells with the

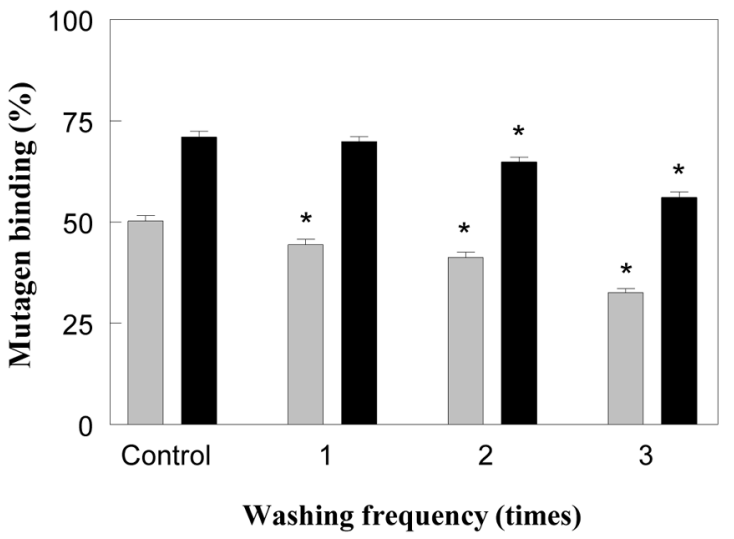

Fig. 3 Effects of washing frequency on L. paracasei subsp. tolerans JG22 strain-MNNG $(\square)$ or 2-NF ( $\square$ ) complex. Bars represent means of triplicate assays and error bars represent SD. *Significantly differ ( $p$ $<0.05$ ) from the control group by paired t-test.

mutagen may contribute to the antimutagenicity of JG22 strain against MNNG and 2-NF. JG22 strain which exhibited timedependent inhibition of mutagenic activity toward MNNG and 2NF could be chiefly attributed to the interaction between the cells and the mutagen. These results on the effect of the reaction time on the antimutagenic activity are in agreement with the finding by Hung et al. (2009).

Stability of mutagen binding. The mutagen-binding capacity of L. paracasei subsp. tolerans JG22 and the effect of washing with buffer on releasing of the bound mutagen are displayed in Fig. 3. Initially the amounts of MNNG and 2-NF by JG22 strain were removed by 50 and $71 \%$, respectively. When washing JG22 strain-mutagen complexes, the variable amounts of the mutagen bound by the bacteria were released back into solution. After one wash with PBS, JG22 strain retained 44 and $69 \%$ of MNNG and 2-NF present in the original incubation solution, respectively. The viable cells of JG22 strain washed three with PBS expressed the mutagen binding of 33 and $56 \%$ against MNNG and 2-NF, respectively. The amount of mutagen bound and the stability of the complexes formed between lactobacilli and mutagen was strain specific. Lactobacillus strains bound 17.3 to $59.7 \%$ aflatoxin $\mathrm{B}_{1}$, Bifidobacterium strains bound 18.0 to $48.7 \%$, and Lactococcus ssp. strains bound 5.6 to $41.1 \%$ the mutagen. And the bacterial binding of aflatoxin $\mathrm{B}_{1}$ by Lactobacillus amylovorus and L. rhamnosus was rapid and reversible, and this mutagen was released by repeated aqueous washes (Peltonen et al., 2001). Haskard et al. (2000) noted that the release of the bound mutagens could be very specific to the washing solution employed and the stability of the complexes formed depends on strain and treatment and environmental conditions.

Thus, the release of MNNG and 2-NF from the complex was relatively linear with respect to the number of washes. The release of MNNG and 2-NF in washes of the complex might be attributed to interactions between the mutagen molecules and the cellular surface, and the antimutagenic factor(s) of this strain may be 


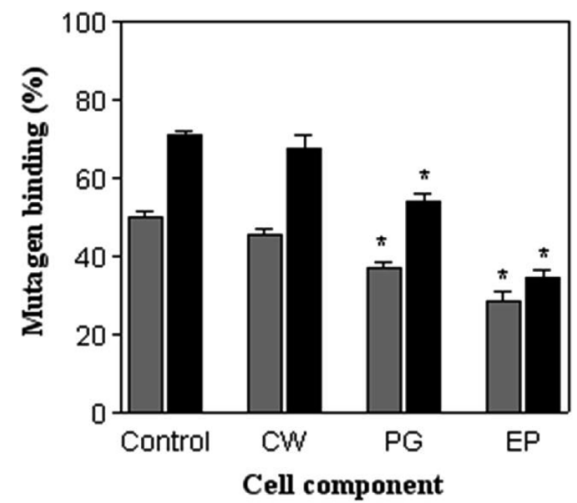

Fig. 4 Mutagen binding of the whole cells (control), cell wall fractions $(\mathrm{CW})$, exopolysaccharides (EP), and peptidoglycans (PG) obtained from L. paracasei subsp. tolerans JG22 strain on the mutagenicity induced by MNNG ( $\square$ ) and 2-NF ( $\square$ ). Bars represent means of triplicate assays and error bars represent SD. *Significantly differ $(p<0.05)$ from the control group by paired t-test.

identical to the extracellular antimutagenicity components. These observations indicate that the mechanism of mutagen removal by $\mathrm{LAB}$ has been suggested as binding of mutagen to the bacterial cell wall or to the cell wall components rather than the metabolic degradation. Morotomi and Mutai (1986) demonstrated that such binding may take place as a result of cation exchange of mutagen with the cell wall peptidoglycan or involvement of carbohydrate or protein structures. Therefore, the destruction of specific components of the bacterial cell wall resulted in the reduction of aflatoxin $\mathrm{B}_{1}$ binding by L. rhamnosus strain GG (Haskard et al., 2000). Several studies suggested that the differences in the mutagen binding by the strains are probably due to different bacterial cell wall and cell envelope structures (Sreekumar and Hosono, 1998b; Haskard et al., 2001).

Antimutagenic effect of cell wall fractions, peptidoglycans, and exopolysaccharides. The relative binding of MNNG and 2$\mathrm{NF}$ by the cell fractions and the cell wall components including peptidoglycans and exopolysaccharides from $L$. paracasei subsp. tolerans JG22 strain is shown in Fig. 4. The whole cells showed stronger binding of MNNG and 2-NF than cell wall fraction, exopolysaccharide, and peptidoglycan. The cell wall fractions of the strain JG22 bound MNNG and 2-NF to the extent of 47.5 and $68.9 \%$, respectively. There was no significantly difference in between the whole cells and the cell walls. The peptidoglycans obtained from the strain also bound 38.1 and $53.9 \%$ of the available MNNG and 2-NF, respectively. The binding activity of the peptidoglycans of JG22 strain was higher than that of the exopolysaccharides of cell walls. These results are consistent with the findings of Sreekumar and Hosono (1998d), who reported that some exopolysaccharides produced by LAB may have the ability to bind mutagens.

The cell walls have bound amino acid pyrolyzates more effectively than pure peptidoglycan, and this has been attributes to the removal of surface polysaccharides in the extraction of peptidolgycan (Sreekumar and Hosono, 1998b). The cell wall polysaccharides contain the amino acid pyrolysates binding sites of Lactobacillus gasseri and their intact glucose molecules have a significant role in the binding of amino acid pyrolyzate, 3-amino1,4-dimethyl-5H-pyrido [4,3-b] indole (Trp-P-1), while the involvement of proteins had been ruled out (Park et al., 1998). Zhang and Ohta (1993) reported that because the whole cell and cell wall skeleton of Streptococcus cremoris Z-25 had greater the binding activity, but the cytoplasm and extract of cell wall skeleton did not bind Trp-P-1 and Trp-P-2. Also, the peptidoglycan complex and the polysaccharides liberates from cell wall skeleton of S. cremoris Z-25 showed strong binding of Trp-P-2. Zhang and Ohta (1991) indicated that the peptidoglycans isolated from the cell wall of $L$. acidophilus IFO13951 could suppress the mutagenesis induced by Trp-P-2. Rajendran and Ohta (1998) reported that the cell wall polysaccharide and peptidoglycan are the two main elements responsible for the binding of mutagens to LAB. Haskard et al., (2001) revealed that the hydrophobic interactions between the exopolysaccharides of the cells and the mutagen play a major role in the binding mechanisms.

Meanwhile, Zhang and Ohta (1993) found that peptidoglycan of $L$. acidophilus IFO 13951, outer membrane and cytoplasmic membrane of Escherichia coli IFO4249, and glucan or mannan isolated from cell wall of Saccharomyces cerevisiae exhibited the binding ability to Trp-P-1. Thus, the antimutagenic activity of probiotics depends on many factors such as the kinds of species, chemical structure of cell walls, and chemical complexity of mutagens (Sreekumar and Hosono, 1998b).

Influenceof different treatments on antimutagenic effect. Influences of $\mathrm{pH}$, heating, enzymes, metal salts, artificial gastric and intestinal juices, and sodium metaperiodate on the cell viability and the mutagen binding of $L$. paracasei subsp. tolerans JG22 strain are shown in Table 2. To determine the influence of physical, chemical, and enzymatic treatments on the survival and the mutagen binding of JG22 strain, the cell suspensions were replaced with buffer treated in respective conditions and preincubated with or without MNNG or 2-NF.

JG22 strain revealed a relatively high viability in $\mathrm{pH} 2.0-5.0$ buffer solution for $2 \mathrm{~h}$ by maintaining the viable cell counts above $8 \mathrm{Log}$ CFU/mL. Moreover, the strain survived at a level of $9 \mathrm{Log}$ $\mathrm{CFU} / \mathrm{mL}$ in $\mathrm{pH}$ 6.0-9.0 buffer, there was no significantly difference $(p>0.05)$ in cell viability between the initial cell counts and the cells after treatment. Therefore, the treatment of the strain at acidic, neutral, and alkaline $\mathrm{pH}$ had no significant influence $(p>0.05)$ on the mutagen binding of JG22 strain, suggesting that the cell wall structures of this bacteria needed for the mutagen binding were not irreversibly affected at extreme $\mathrm{pH}$ values. The bacterial binding of mutagen by the strain was highly independent on $\mathrm{pH}$, so hydrogen bonding interactions do not appear to be involved in mutagen binding of this strain. El-Nezami et al. (1998b) and Haskard et al. (2000) reported that $\mathrm{pH}$ values in the ranges from 2.5 to $8.5 \mathrm{did}$ not appear to contribute to the release of aflatoxin $B_{1}$. By contrast, Zhang and Ohta (1991b) demonstrated that the greatest extent of binding of mutagenic pyrolyzates to cells of LAB in vitro occurs between $\mathrm{pH}$ values of 6 and 7 . 
Table 2 Effects of pretreating L. paracasei subsp. tolerans JG22 on the cell viability and its ability to bind MNNG and 2-NF

\begin{tabular}{|c|c|c|c|c|}
\hline \multirow{2}{*}{\multicolumn{2}{|c|}{ Pretreatments }} & \multirow{2}{*}{ Viability (\%) } & \multicolumn{2}{|c|}{ Mutagen binding (\%) } \\
\hline & & & MNNG $(1 \mu \mathrm{g} /$ plate $)$ & 2-NF $(1 \mu \mathrm{g} /$ plate $)$ \\
\hline \multicolumn{2}{|c|}{ No treatment } & 100 & $50.28 \pm 2.33$ & $71.27 \pm 1.15$ \\
\hline \multirow{8}{*}{$\mathrm{pH}$} & 2.0 & $1.34 \pm 0.59 *$ & $46.35 \pm 3.50$ & $69.38 \pm 3.26$ \\
\hline & 3.0 & $3.32 \pm 0.92 *$ & $48.28 \pm 4.52$ & $70.25 \pm 4.82$ \\
\hline & 4.0 & $6.51 \pm 0.61^{*}$ & $49.50 \pm 3.08$ & $68.22 \pm 2.99$ \\
\hline & 5.0 & $7.84 \pm 0.50 *$ & $47.91 \pm 3.58$ & $69.11 \pm 3.07$ \\
\hline & 6.0 & $99.7 \pm 0.15$ & $51.15 \pm 4.46$ & $72.65 \pm 4.23$ \\
\hline & 7.0 & $99.9 \pm 0.22$ & $48.48 \pm 2.76$ & $68.39 \pm 1.81$ \\
\hline & 8.0 & $99.8 \pm 0.20$ & $47.33 \pm 4.46$ & $70.58 \pm 2.85$ \\
\hline & 9.0 & $99.5 \pm 0.18$ & $49.04 \pm 3.87$ & $69.27 \pm 1.80$ \\
\hline \multirow{3}{*}{ Heating } & $80^{\circ} \mathrm{C}, 60 \mathrm{~min}$ & $<0.01 *$ & $22.44 \pm 0.94 *$ & $39.35 \pm 4.55^{*}$ \\
\hline & $100^{\circ} \mathrm{C}, 30 \mathrm{~min}$ & ND* & $11.89 \pm 1.42 *$ & $25.02 \pm 6.01 *$ \\
\hline & $121^{\circ} \mathrm{C}, 15 \mathrm{~min}$ & ND* & $4.94 \pm 1.83^{*}$ & $13.23 \pm 5.34^{*}$ \\
\hline \multirow{7}{*}{ Enzymes } & $\alpha$-Amylase & $90.3 \pm 0.64$ & $9.41 \pm 0.74^{*}$ & $11.35 \pm 2.87^{*}$ \\
\hline & Lysozyme & $85.4 \pm 0.49$ & $7.56 \pm 1.88 *$ & $10.35 \pm 2.03 *$ \\
\hline & Pepsin & $82.3 \pm 1.39$ & $48.01 \pm 1.33$ & $64.08 \pm 4.03$ \\
\hline & Protease & $88.7 \pm 0.71$ & $47.33 \pm 1.53$ & $62.98 \pm 3.55$ \\
\hline & Trypsin & $86.2 \pm 1.38$ & $46.27 \pm 4.23$ & $66.32 \pm 2.87$ \\
\hline & Chemotrypsin & $87.4 \pm 0.53$ & $48.93 \pm 2.53$ & $65.99 \pm 2.80$ \\
\hline & Lipase & $95.1 \pm 1.27$ & $49.04 \pm 3.01$ & $69.13 \pm 4.99$ \\
\hline \multirow{3}{*}{ Metal salts } & $\mathrm{NaCl}$ & $93.4 \pm 2.09$ & $50.76 \pm 2.75$ & $67.04 \pm 0.94$ \\
\hline & $\mathrm{CaCl}_{2}$ & $91.1 \pm 0.74$ & $17.36 \pm 5.05^{*}$ & $30.27 \pm 1.50 *$ \\
\hline & $\mathrm{MgCl}_{2}$ & $92.7 \pm 1.51$ & $28.28 \pm 3.79 *$ & $39.06 \pm 3.66^{*}$ \\
\hline \multirow{3}{*}{$\begin{array}{l}\text { Artificial gastric and intestinal } \\
\text { juices }\end{array}$} & Pepsin (pH 2.0) & $0.94 \pm 0.21 *$ & $46.74 \pm 1.88$ & $62.18 \pm 2.53$ \\
\hline & $0.5 \%$ Oxgall & $45.5 \pm 1.03 *$ & $50.73 \pm 3.54$ & $69.59 \pm 2.92$ \\
\hline & Sodium metaperiodate & $92.4 \pm 0.55$ & $17.43 \pm 2.66^{*}$ & $11.97 \pm 5.42 *$ \\
\hline
\end{tabular}

Results are presented as means \pm SD for three plates.

* Significantly differ $(p<0.05)$ from the control group by paired t-test.

Bolognani et al.(1997) reported that the efficiency with which the mutagen binding of $B$. longum was greatest at $\mathrm{pH} 5$, but the binding capacity declined markedly at above or below $\mathrm{pH} 5$.

The cells heated for $60 \mathrm{~min}$ at $80^{\circ} \mathrm{C}$ exhibited the mutagen binding against MNNG and 2-NF by 22.4 and $39.4 \%$, respectively. The cells which completely lost the viability by heating for $15 \mathrm{~min}$ at $121^{\circ} \mathrm{C}$ showed very low levels of the mutagen binding. Thus, the live cells of JG22 strain showed the higher mutagen binding than the heat-killed cells. Since the mutagen binding of JG22 strain was significantly reduced by heating, the treatment with heat had some effect on the extracellular substances of the bacterial structures involved in the mutagen binding. Heat shock can influence the normal functionality of the bacterial cell wall and damage their physiological and vital activities, and that eventually causes cell injury and death (Tabatabaie and Mortazavi, 2008). Lankaputhra and Shah (1998) demonstrated that the live cells of probiotic bacteria showed higher antimutagenic activity and their efficiency in inhibiting the mutagens was better than killed bacterial cells. Besides, the live bacterial cells bound or inhibited the mutagens permanently, whereas the killed bacteria released the mutagens upon the extraction with DMSO. These findings are in disagreement with the result of Zhang et al. (1990), who reported that the binding of mutagenic pyrolyzates by thermally killed cells of $S$. cremoris and Streptococcus lactis as well as the viable cells displayed high binding activity.

In the cell viability and the mutagen binding, no significant difference $(p>0.05)$ between the untreated cells and the cells treated with pepsin, protease, trypsin, chemotrypsin, and lipase was observed. However, the mutagen binding of JG22 strain was significantly reduced $(p<0.05)$ by the pretreatment of $\alpha$-amylase and lysozyme for $2 \mathrm{~h}$ at $37^{\circ} \mathrm{C}$. All used enzymes did not significantly $(p>0.05)$ affect the viability of this strain. The absence of a significant effect from the viable bacterial pretreatment with pepsin, protease, trypsin, and chemotrypsin implies that proteins have negligible involvement in mutagen binding by JG22 cells. Besides, the treatment with lipase did not cause a significant decrease in MNNG and 2-NF binding, suggesting that lipids such as lipoteichoic acid is unlikely to be involved in the binding of two mutagens. Treatment with $\alpha$-amylase and lysozyme caused significant decrease in MNNG and 2-NF binding for JG22 strain, suggesting that carbohydrates in the cell walls may be involved in their antimutagenic activity. These results are in discordance with 
the previously reported some studies. The antimutagenic activity of $P$. shermanii VKM-103 against 9-aminoacridine was found in the protein fraction of the cell extract because it was considerably reduced by protease treatment and dialysis (Vorobjeva et al., 2001).

Furthermore, the strain had the comparatively high survival ratio under metal ions. The mutagen binding and the cell viability of JG22 strain against two mutagens did not change after pretreatment with metal ion such as $\mathrm{NaCl}$. However, the binding of this bacteria was significantly lower $(p<0.05)$ in the presence of divalent ions than monovalent ion. The results obtained in this study showed that electrostatic interactions have major influence on the mutagen binding. Metal ions have previously been reported to inhibit the binding of mutagen to $\mathrm{LAB}$, but monovlaent ions had the least effect (Haskard et al., 2000). The chelation of metal ions by the $\beta$-dicarbonyl moiety of aflatoxin $B_{1}$ has been implicated in the binding of mutagen by phyllosilicate clay (Oatley et al., 2000). The ability of bacterial cell walls to bind cations, especially divalent cations, arises from the presence of acidic centers in the cell wall structure such as lipoteichoic acids which protrude from the cell surface (El-Nezami et al., 2004). Lahtinen et al. (2004) concluded that the specific cation may reduce aflatoxin $B_{1}$ binding by blocking possible interactions between aflatoxin $B_{1}$ and teichoic acids on the surfaces of bacterial cell walls.

Although pepsin treatment at $\mathrm{pH} 2.0$ for $2 \mathrm{~h}$ caused ca. $2 \log$ $\mathrm{CFU} / \mathrm{mL}$ reduction in the viability of cells in comparison to control, the binding capacity was not affected by the simulated gastric juice. The cells preincubated in artificial intestinal juice containing 5\% oxgall showed the mutagen binding similar to the control. The binding of MNNG and 2-NF to the cells of JG22 strain partially inactivated by acidic $\mathrm{pH}$ and bile salts did not change to a large extent in the treated cells under acidic $\mathrm{pH}$ and bile salts compared with the control. Therefore, it may be likely that hydrogen bonding is not important and the bacterial binding against MNNG and 2-NF may be occurring in any point along the gastrointestinal tract like the results of El-Nezami et al. (2004). Conway et al. (1987) indicted that the better survival of $L$. acidophilus $\mathrm{ADH}$ at $\mathrm{pH} 1.0$ to 5.0 might be related to its cell wall protection. Sreekumar and Hosono (1998a) found that the binding of Trp-P-1 by L. gasseri and B. longum was significantly increased as $\mathrm{pH}$ value increased. These findings suggest that $\mathrm{pH}$-dependent binding of mutagens by LAB may be widely different. Yamada et al. (1993) suggested that cholic, taurocholic, and glycocholic acids and their amino acid components (taurine and glycine) decreased the mutagenicity of certain mutagens. Lo et al. (2004) showed that the antimutagenic activity of $B$. lactis $\mathrm{Bb}-12$ against the mutagen was increased as $\mathrm{pH}$ values were increased from 2.0 to 7.0 , while the antimutagenic activity was decreased as bile salt concentration was increased from 0.5 to $2.0 \%$. Besides, the increase of the antimutagenicity for bifidobacteria after bile treatment may be due to the formation of some bile acids resulting in the modification of benzo[a]pyrene mutagenicity.

The mutagen binding of the cells against MNNG and 2-NF was considerably reduced $(p<0.05)$ after treatment with sodium metaperiodate, which did not affect the cell viability. Carbohydrates consisting of the cell walls may be important elements responsible for the binding of MNNG and 2-NF by JG22 strain, because the mutagen binding of this strain was decreased by sodium metaperiodate which acts mainly on carbohydrate. Carbohydrate components occur in three main forms in the walls of bacterial cells: peptidoglycans, polysaccharides, and lipoteichoic acids or teichoic acids. Hence, both $\alpha$-amylase and sodium metaperodate which may change the original binding site of the viable bacteria have a significant effect on the mutagen binding, this may suggest the binding interaction appears to occur predominantly with carbohydrate components of the bacteria. Our results are consistent with the results of Haskard et al. (2000), who demonstrated the treatment with sodium metaperiodate which oxidizes cis $\mathrm{OH}$ groups to aldehydes and carbon acid groups caused the largest decrease in the mutagen binding, suggesting that a polysaccharide component on the bacterial surface is essential for the binding.

These results demonstrated that the mutagen binding to the cells after chemical, physical, and enzymatic treatments was different depending on the mutagen and pretreatment conditions. The binding activity of the mutagen by JG22 strain seems to be affected by heating, enzymes including $\alpha$-amylase and lysozyme, divalent ions, and sodium metaperiodate.

In conclusion, the viable L. paracasei subsp. tolerans JG22 isolated from pepper leaf jangajji, exhibited strong antimutagenic activity against MNNG and 2-NF in vitro. Thus, the mutagen binding of JG 22 strain may play a vital role in suppressing the process of mutagenesis induced by mutagens. In the future, further studies are needed to elucidate the precise mechanisms for the mutagen removal by JG22 strain and in vivo bacterial-mutagen complex stability.

\section{References}

Ambalam P, Dave JM, Nair BM, and Vyas BRM (2011) In vitro mutagen binding and antimutagenic activity of human Lactobacillus rhamnosus 231. Anaerobe 17, 217-22.

Bolognani F, Rumney CJ, and Rowland R (1997) Influence of carcinogen binding by lactic acid producing bacteria on tissue distribution and in vivo mutagenicity of dietary carcinogens. Food Chem. Toxicol 35, 53545 .

Burns AJ and Rowland IR (2004) Antigenotoxicity of probiotics and prebiotics on faecal water-induced DNA damage in human colon adenocarcinoma cells. Mutat Res 551, 233-43.

Cassand P, Abdelali H, Bouley C, Denariaz G, and Narbonne JF (1994) Inhibitory effect of dairy products on the mutagenicities of chemicals and dietary mutagens. J Dairy Res 61, 545-52.

Conway PL, Gorbach SL, and Goldin BR (1987) Survival of lactic acid bacteria in the human stomach and adhesion to intestinal cells. J Dairy Sci 70, 1-12.

De Flora S, Izzoth A, and Benniceili C (1992) Mechanisms of antimutagenesis and anticarcinogenesis, Role in primary protection. InAntimutagenesis and anticarcinogenesis mechanisms, pp. 162-78. Plenum Press, New York, USA.

El-Nezami H, Salminen S, Ahokas J, and Kannkaanpaa P (1998a) Ability of dairy strains of lactic acid bacteria to bind a common food carcinogen, aflatoxin $\mathrm{B}_{1}$. Food Chem Toxicol 36, 321-6. 
El-Nezami H, Kankaanpas P, Salminen S, and Ahokas J (1998b) Physicochemicals alterations enhance the ability of dairy strains of lactic acid bacteria to remove aflatoxin from contaminated media. J Food Prot 61, 466-8.

El-Nezami H, Polychronaki N, Lee YK, Haskard C, Juvonen R, Salminen S et al. (2004) Chemical moieties and interactions involved in the binding of zearalenone to the surface of Lactobacillus rhamnosus strains GG. $J$ Agric Food Chem 52, 4577-81.

Faridnia F, Hussin AS, Saari N, Mustafa S, Yee LY, and Manap MY (2010) In vitro binding of mutagenic heterocyclic aromatic amines by Bifidobacterium psedocatenulatum G4. Benef Microbes 1, 149-54.

Ferguson LR (2002) Natural and human-made mutagens and carcinogens in the human diet. Toxicol 181, 79-82.

Gaubatz JW (1997) Heart damage associated with cooked meat mutagens. Nutr Biochem 8, 490-6.

Gomes AMP and Malcata FX (1999) Bifidobacterium spp., and Lactobacillus acidophilus: biological, biochemical, technological and therapeutica properties relevant for use as probiotics. Trends Food Sci Technol 10, 139-57.

Gopal PK and Reilly KI (1995) Molecular architecture of the lactococcal cell surface as it relates to important industrial properties. Int Dairy $J \mathbf{5}$, 1095-111.

Haskard C, Binnion C, and Ahokas J (2000) Factors affecting the sequestration of aflatoxin by Lactobacillus rhamnosus strain GG. Chem Biol Interact 128, 39-49.

Haskard C, El-Nezami H, Kannkaanpaa P, Salminen S, and Ahokas J (2001) Surface binding of aflatoxin $\mathrm{B}_{1}$ by lactic acid bacteria. Appl Environ Microbiol 67, 3086-91.

Hirayama K and Rafter J (2000) The role of probiotic bacteria in cancer prevention. Microb Infect 2, 681-6.

Hosono A, Kashina T, and Kada T (1986) Antimutagenic properties of lactic acid-cultured milk on chemical and fecal mutagens. J Dairy Sci 69, 2237-42.

Hung YH, Wang YJ, and Chou CC (2009) Antimutagenic activity of Aspergillus awamori-fermented black soybean response to simulated digestive juice treatments and its antimutagenic mechanisms. LWT-Food Sci Technol 42, 56-62.

Kim SY, Shon YH, Lee JS, Kim CH, and Nam KS (2000) Antimutagenic activity of soybeans fermented with basidiomycetes in Ames/Salmonella test. Biotechnol Lett 22, 1197-202.

Kodym A and Afza R (2003) Physical and chemical mutagenesis. Method Mol Biol 236, 189-203.

Lahtinen SJ, Haskard CA, Ouwehand AC, Salminen SJ, and Ahokas JT (2004) Binding of aflatoxin $\mathrm{B}_{1}$ to cell wall components of Lactobacillus rhamnosus strain GG. Food Addit Contam 21, 158-64.

Lankaputhra WEV and Shah NP (1998) Antimutagenic properties of probiotic bacteria and of organic acids. Mutat Res 39, 169-82.

Lo PR, Yu RC, Chou CC, and Huang EC (2004) Determinations of the antimuagenic activities of several probiotic bifidobacteria under acidic and bile conditions against benzo[á]pyrene by a modified Ames test. Int J Food Microbiol 93, 249-57.

Lo PR, Yu RC, Chou CC, and Tsai YH (2002). Antimutagenic activity of several probiotic Bifidobacteria against benzo[á]pyrene. J Biosci Bioeng 94, 148-53.

Maron DM and Ames BN (1983) Revised methods for Salmonella mutagenicity test. Mutat Res 113, 173-215.

Mobarez AM, Doust RH, Hassan ZM, and Kamali S (2007) Antimutagenic effect of Lactobacillus acidophilus and Lactobacillus bulgaricus isolated from Iranian yoghurt on 2-nitrofluorene. Res J Microbiol 2, 524-9.

Morotomi M and Mutai M (1986) In vitro binding of potent mutagenic pyrolysates by intestinal bacteria. J Natl Cancer Inst 77, 195-201.

Nadathur SR, Gould SJ, and Baklynaski AT (1994) Antimutagenicity of fermented milk. J Dairy Sci 77, 3287-95.
Oatley JT, Rarck MD, Ji GE, and Linz JE (2000) Binding of aflatoxin $\mathrm{B}_{1}$ to bifidobacteria in vitro. J Food Prot 63, 1133-6.

Orrhage K, Sillerstrom E, Gustafsson JA, Nord CE, and Rafter J (1994) Binding of mutagenic heterocyclic amines by intestinal and lactic acid bacteria. Mutat Res 311, 239-48.

Park KY, Kim SH, and Son TJ (1998) Antimutagenic activities of cell wall and cytosol fractions of lactic acid bacteria isolated from kimchi. J Food Sci Nutr 3, 329-33.

Park HD and Rhee CH (2001) Antimutagenic activity of Lactobacillus plantarum KLAB21 isolated from kimchi Korean fermented vegetables. Biotechnol Lett 23, 1583-9.

Paul TJ, Scheepers M, Straetemans ME, and Joop P (1994) Nitroreduction and formation of hemoglobin adducts in rats with a human intestinal microflora. Environ Health Persp 47, 587-99.

Peltonen K, El-Nezami H, Haskard C, Ahokas J, and Salminen S (2001) Aflatoxin $\mathrm{B}_{1}$ binding by dairy strains of lactic acid bacteria and bifidobacteria. J Dairy Sci 84, 2152-6.

Pool-Zobel BL, Neudeke C, Domizlaff I, Ji S, Schillinger U, Rumney C et al. (1996) Lactobacillus- and Bifidobacterium mediated antigenotoxicity in the colon of rats. Nutr Cancer 26, 365-80.

Rajendran R and Ohta Y (1998) Binding heterocyclic amines by lactic acid bacteria from miso and fermented. Jpn Food Can J Microbiol 44, 10915.

Ruan C, Liang Y, and Liu Z (1989) Inhibition of twelve Chinese traditional medicinal herbs on mutagenic effect induced by aflatoxin $\mathrm{B}_{1}$. Chin $J$ Cancer 1, 29-31.

Singer B and Kusmierek JT (1982) Chemical mutagenesis. Ann. Rev. Biochem. 51, 655-91.

Sreekumar O and Hosono A (1998a) Amino acid pyrolysates competitive and combination binding with Lactobacillus gasseri cells. Milchwissenschaft 53, 73-6.

Sreekumar O and Hosono A (1998b) Antimutagenic activity and influence of physical factors in binding Lactobacillus gasseri and Bifidobacterium longum cells to amino acid pyrolysates. J Dairy Sci 81, 1508-16.

Sreekumar O and Hosono A (1998c) The antimutagenic properties of a polysaccharide produced by Bifidobacterium longum and its cultured milk against some heterocyclic amines. Can J Microbiol 44, 1029-36.

Sreekumar O and Hosono A (1998d) The heterocyclic amino binding receptors of Lactobacillus gasseri cells. Mutat Res 421, 65-72.

Srinivasan P, Sabitha KE, and Shyamaladevi CS (2007) Attenuation of 4nitroquinoline 1- oxide induced in vitro lipid peroxidation by green tea polyphenols. Life Sci 80, 1080-6.

Tabatabaie F and Mortazavi A (2008) Studying the effects of heat and cold shock on cell wall microstructure and survival of some LAB in milk. World Appl Sci J 4, 191-4.

Vorobjeva LI, Iljasova OV, Khodjaev EY, Ponomareva GM, and Varioukhina SY (2001) Inhibition of induced mutagenesis in Salmonella typhimurium by the protein of Propionibacterium freudenreichii subsp. shermanii. Anaerobe 7, 37-44.

Yamada K, Lim BO, Nonaka M, and Sugano M (1993) Measurements of mutagenic and antimutagenic activities of bile acids by Rec-assay. Biosci Biotechnol Biochem 57, 599-602.

Zhang XB and Ohta Y (1990) Antimutagenicity and binding of lactic acid bacteria from Chinese cheese to mutagenic pyrolyzates. J Dairy Sci 73, 2702-10.

Zhang XB and Ohta Y (1991a) Binding of mutagens by fractions of the cell wall skeleton of lactic acid bacteria on mutagens. J Dairy Sci 74, 147781.

Zhang XB and Ohta Y (1991b) In vitro binding of mutagenic pyrolysates to lactic acid bacterial cells in human gastric juice. J Dairy Sci 74, 752-7.

Zhang XB and Ohta Y (1993) Antimutagenic activity of cell fractions of microorganisms on potent mutagenic pyrolysates. Mutat Res 298: 24753. 